barograph, and a Redier's barograph. My observations, made alternately with these four, came to the same result. If the wind appeared to have lulled for a short time, there would be a sudden fall in the barometer of often more than two millimetres. A violent gust would then follow on the fall in the barometer, its strength varying in proportion to the fall of the barometer. During the gust the barometer would rise nearly as much as it had previously fallen.

From these observations, carried on through whole days, and often far into the night, it seemed to me that the cause of the gusts must be that slight, quickly passing depressions were over us.

If these observations are correct, and I can hardly doubt them, the suction of the wind is of secondary importance in considering the causes of the "pumping" (" oscillations").

I cannot allow myself to enter into all the interesting meteorological subjects that there presented themselves, and my views upon them, without trespassing too largely on the space assigned to me in these pages. I would only refer briefiy to what I observed of the marked electrical activity in the telephone. It may seem strange to speak of a strong electrical development in winter, and I must confess to have been surprised on many days to hear a loud crackling at the telephone, so loud that it was almost impossible to speak through it. Still more astonished was I to see electric sparks going off from the electric plate ("Blitz Platte"). Unfortunately I had not time to examine this increased electric activity in its relation to the weather; but I fancied that a fall of snow with a south wind had most influence upon it. I requested Lechner to make daily observations of the crackling in the telephone, at a given hour, and to register the four stages-weak $=\mathrm{I}$, moderate $=2$, strong $=3$, electric sparks $=4$. I have heard from him that he has been recording his observations five times a day, and, he thinks, with good result. A prolonged series of observations will easily determine its cause.

From these hastily collected extracts of my experiments and investigations on the Sonnblick, all must be satisfied of what great importance to science is the Observatory on its summit, and not less to Alpinists. It matters little how highly I prize it ; my aim is to make its value known in wider circles.

But it behoves us, scientific men and tourists, not merely to wax enthusiastic over the Sonnblick Observatory, but to take measures to ensure its permanency. I am aware that the Alpine Club has already done its part, ${ }^{1}$ and do not doubt but that in future it will shrink from no sacrifice to uphold and support this, its foster child, which, in conjunction with the Meteorological Society, it has brought into life. But I am inclined to think that there are nearer supporters of this our most important mountain Observatory, on whom there exists a prior claim. I am under the impression that certain influential members of the Alpine Club had been called upon to form a special Sonnblick Verein, part scientific, part tourist, who by a small yearly subscription should ensure the keeping up of this invaluable station.

My descent from the Sonnblick began on March 4, amid a storm of north wind, mist, and temperature at $-22^{\circ} \mathrm{F}$. We rode down on miners' sledges (Knappenrossen), but even then had great difficulty in forcing a passage, snow having fallen knee-deep overnight. We often had to call a halt, and wade through the snow, thereby causing great delay; it took us two hours to reach Kolm, a distance usually accomplished in one.

On March 5 I reached Rauris; leaving on the 6th with Dr. Trabert for Lend. Even on these two last days, the weather followed us with unremitting severity. The way

${ }^{1}$ The corporation of the Alpine Club has just signed an agreement with Herr Rojacher, by which it guarantees him a grant of $5000 \mathrm{fl}$. towards the enlargement of the Sonnblick Observatory.

NO. IO8I, VOL. 42] from Kolm to Rauris had been made under a heavy snowfall; and in the night of the 5th-6th there were such deep snow-drifts, that we were two hours making our way from Rauris to Landsteg.

On March 7 we reached Vienna.

\section{"BEDFORD COLLEGE.}

SOME time ago we drew attention to the fact that Bedford College, which has done so much for the education of women, was in need of funds. The new laboratories are now in use, but they are not yet paid for, and the stock of apparatus is not all that could be desired. Our readers will remember that $\mathrm{Mr}$. Henry Tate had promised a donation of $£$ IOoo provided the Council could raise a like amount from other sources. We believe that the College authorities are nearly in a position to claim his generous gift; but though this will free the building itself from debt, at least $f 500$ more is wanted to pay for equipment on a very moderate scale.

The last twelve months have been, in matters educational, a ladies' year; but the true meaning of the successes which have been won at Cambridge and elsewhere will be missed, if they are regarded only as a nine days wonder, or as proving ambulando that the higher levels of undergraduate attainment can be reached by girls. The lesson which has been so strikingly enforced is that no branch of learning is the exclusive property of either sex, and that girls are wronged if we do not afford them the same opportunities for acquiring knowledge which are provided for their brothers.

The founders of Bedford College acted on this principle when it was not so widely accepted and not so self-evident as in 1890 , and we can only urge on the friends of the education of women not to forget, in the hour of their triumph, the toilers who have paved the way to their success.

In an unpretending building in an uninteresting London street an effort has for long been made to supply education of the highest class for London girls. Faith in the future and effort in the present have never been wanting, even when the story of the past seemed most discouraging. The College is now undeniably a success, but it is still sadly hampered by want of means. The adequate equipment of its laboratories is surely an object for which an appeal will not be made in vain to those who believe that the benefits which science can confer will never be fully attained till a knowledge of its main principles and methods forms part of the training of all educated men and all educated women alike.

\section{NOTES.}

WE regret to have to record the death of Mr. William Kitchen Parker, F.R.S., formerly Hunterian Professor of Comparative Anatomy at the Royal College of Surgeons. Next week we hope to give some account of his services to science.

A REUTER's telegram from New York states that the remains of the Swedish inventor, John Ericsson, will be conveyed to Sweden by one of the two new American war-vessels, Baltimore and Philadelpinia.

THE Dutch Academy of Sciences in Haarlem has offered a gold medal of the value of 150 gulden for the best work in each of the following subjects:-(I) Researches on the part played by bacteria in the decomposition and formation of nitrogenous compounds in various kinds of soil ; (2) Microscopic investigation of the mode in which different parts of plants can unite with one another, and especially the phenomena which accompany healing after the operation of grafting. The papers must be written in German, Dutch, or Latin (not in the handwriting of the author), and must be forwarded to Dr. J. Bosseka Haarlem, by January I, I89r. 